\title{
The Impact of Discretionary Accruals on Corporate Investment Decisions: Evidence from GCC Countries
}

\author{
Goksel Acar \\ CCBA, Department of Finance and Economics, \\ Dhofar University, Salalah, Oman \\ Corresponding Author \\ Ilker Yilmaz \\ CCBA, Department of Accounting, \\ Dhofar University, Salalah, Oman
}

DOI: https://doi.org/10.36941/ajis-2020-0124

\begin{abstract}
The aim of the article is to examine the relationship between the level of discretionary accruals and corporate investment decisions by using the data of listed production firms from six Gulf Cooperation Council (GCC) countries for the period 2009-2015. We firstly generated discretionary accruals using performance adjusted model introduced by Kothari, et al. (2005). Secondly, we constructed six models to see the relationship between discretionary accruals and investment decisions. To control for country and time effects, we added GDP growth rates of countries as a macroeconomic indicator in all models. Our findings reveal a weak emphasis of discretionary accruals on two dependent variables. Mean accruals are negative for all years and for all countries, and it shows that companies tend to engage in earnings management practices in order to understate income. The use of PPE as an indicator of investment rates for companies provide more precise results than the use of total assets.
\end{abstract}

Keywords: Earnings management, discretionary accruals, investment decisions, GCC

\section{Introduction}

Corporate investment decisions play a decisive role for the sustainable growth of companies. Many factors directly or indirectly affect these decisions. It has been argued that earnings management may affect corporate investment decisions, such that the firms in pursuit of making a capital expenditure may tend to manipulate earnings in many ways to provide them advantage for bearing the burden of new capital expenditure. The purpose of this article is to examine the relationship between the level of earnings management and corporate investment decisions. Earnings management is the use of several tools including accruals to misreport the profit or loss figures for a variety of purposes. Those purposes may depend on different managerial motives. For instance, one possible reason might be to receive bonuses which are tied to corporate profits, or another reason might be to follow a more stable dividend policy and the question arises as what makes it necessary for management to understate/overstate earnings. The answer to this question seems quite simple; anything which causes the profits to fluctuate, therefore the underlying reasons might be several. One of them is corporate investment 
decisions. The decisions to expand the capacity of the firm by investing in fixed assets may be risky and may take a long period of time to generate a positive return. This situation may affect both the profitability and the cash flows. As a result, it would not be surprising for a firm with high investment amounts to be engaged in earnings management. Then, we raise the research problem as whether there is a relationship between earnings management and investment decisions. In other words, does earnings management practices in a period have a significant effect on the level of investments?

We aim to find out the relationship by using the data of 184 companies from six Gulf Cooperation Council (GCC) countries for the period of 2009-2015. The rest of the paper is organized as follows; next section provides a short review of literature about the topic. Section 3 gives the details about data, methodology and research design. Section 4 provides the results and the discussion, and the last section concludes the findings.

\section{Review of Related Literature}

This section of study firstly considers earnings management literature. It is followed by relationship between financial reporting quality and investment decisions of companies.

When we take a glance at earnings management literature, we can see a strong emphasis on accruals, the researchers concentrate on this concept because they assume accruals as the key instrument to manipulate earnings, beginning from the early attempts to understand the nature of manipulation they focus on estimation of accruals in a precise way. Healy (1985) and DeAngelo (1986) can be counted as the initial contributors those added accruals to earnings management literature, however Jones (1991) does one of the foremost impacts, in her study she examined whether companies manipulate earnings prior to investigation of International Trade Commission (ITC). She estimated accruals as a function of change in revenues, property, plant, and equipment (PPE), total assets. Dechow et al. (1995) made a considerable modification on well-known Jones model and they added change in receivables to the model. This model is called as Modified Jones Model and has been widely accepted and used by many researchers.

Kothari et al. (2005) have argued that the companies with extreme performances can be perceived as manipulating earnings in Jones model and Modified Jones model. Therefore, they introduced two different aspect to literature, firstly, they made matching among companies in a way that they evaluated each company's earnings management score in a set of companies with similar performances and they gathered more precise results than predecessor models. Secondly, they added ROA as a new variable to control the variation causing from performance of companies. This model is also called as performance adjusted model. Kothari et. al (2005) stated more efficient results as well because they reduced heteroskedasticity in regression with the entrance of ROA to model.

In 2008, Cohen et al. (2008) tested real activities earnings management in pre and post SOX periods. They reveal evidence on earnings management using accruals before SOX, whereas there is tendency to manipulate earnings via real activities in the post SOX period. In the last decade, there are numerous studies using real activities manipulation however, models using accruals still attract researchers. Particularly, studies analyzing the relationship of earnings management with any other concept tend to use accruals-based earnings management models in studies.

Kapellas and Siougle (2017) provided a review about this topic. They listed the areas of financial reporting practices which affect investments such as earnings management, information asymmetry/ information environment, accounting quality, investment efficiency. The earnings management may relate to the decisions of investors, managers or regulators. The effect of earnings management on capital investments decisions, which are taken by managers, is an important topic.

One of the most important aims of a firm is to make profit, and in order to achieve this aim, it needs to sustain a productive capacity, which requires capital expenditures. It is expected that the capital expenditures affect positively future earnings, depending on the success of the investments. It is also expectation of the shareholders that capital expenditures must make a positive return; therefore, managers may feel a pressure on themselves and this may lead them to manipulate earnings. Jiang et 
al. (2006) examined the relationship between capital expenditures and earnings by using the data of 357 manufacturing firms at Taiwan Stock Exchange for the period of 1992-2002. They categorized the firms as eight portfolios according to the capital investment ratio. They found that there is a positive relationship between capital expenditures and earnings in the subsequent periods for all the groups.

Biddle and Hilary (2006) conducted a multi-country study hypothesizing that higher accounting quality reduces information asymmetry between managers and creditors and results in enhanced firmlevel investment efficiency. They found consistent results across and within countries.

Zhang (2007) examined the investment-earnings management relationship from a different perspective by using a large dataset covering a 40-year period from 1964 to 2003 , including 118,500 firmyear observations. He searched for the fundamental investment information in accruals and its impact for anomalies in accruals. He found that accruals strongly co-vary with investment in fixed assets and argued that investment information contained in accruals has a first-order effect on accrual anomaly, whereas earnings management has a second-order effect.

The effect of earnings management and more generally the quality of financial reporting on the investments depends on the impact of earnings management on the underlying factors of investment decisions, in other words, it can be claimed that there is an indirect relationship. One of the most important factors affecting firms' investment decisions is cost of capital, therefore the relationship between earnings management/ accounting information quality and cost of capital may be a crucial point. Lambert et al. (2007) examined how the quality of accounting information affects the cost of capital and found that there are direct and indirect effects. The direct effect arises due to the differences in the covariances between the firm with quality disclosures and other firms. The indirect effect takes place when the quality of disclosures changes the firm's real decisions. They concluded that the quality of accounting information can lower the cost of capital.

Li and Tang (2008) examined the impact of discretionary accruals on the pattern and efficiency of subsequent capital investment decisions by using a dataset consisting of 60,728 firm-year observations from 1988 to 2005. Their results showed that fixed asset investments are less sensitive to internal cash flows for the firms with greater positive discretionary accruals and such firms make inefficient investments in fixed assets, resulting in a lower rate of return.

McNichols and Stubben (2008) investigated the effect of earnings management on the investment decisions by identifying the firms manipulating their earnings in three groups, namely firms which were investigated for accounting irregularities, sued by the shareholders for improper accounting, and restated their financial statements. They found that those firms substantially overinvest in tangible fixed assets during the misreporting period, but after that period, they do not overinvest.

Biddle et al. (2009) argued that even though higher quality financial reporting is associated with higher efficiency in investment decisions due to lower investment-cash flow sensitivity, this sensitivity might be related to financing constraints or an excess of cash. Therefore, they questioned that higher quality financial reporting is associated with a reduction of either overinvestment or underinvestment. Their findings suggested that it depends on the cash and leverage of the firms. In other words, if the quality of financial reporting is high, it results in lower investment among the firms which have more cash and are unlevered, but the result is higher investment for the firms with opposite characteristics.

Most of the prior research focused on the effect of earnings management (or earnings quality) on investment decisions. Li (2011) approached in a different perspective, attempting to measure earnings quality by using the capital and labor investment decisions. The results revealed that such measures of earnings quality have a positive correlation with earnings persistence.

Gomariz and Ballesta (2013) investigated the role of financial reporting quality in investment efficiency by considering the debt maturity. They used a sample of Spanish listed companies, consisting of 13,500 firm-year observations for the period of 1998-2008. They found that higher level of financial reporting quality and lower debt maturity result in higher investment efficiency, also the quality of financial reporting causes to reducing overinvestment. More importantly, they presented the evidence of a substitute relationship between lower debt maturity and the quality of financial reporting. The investment efficiency is more affected by the quality of financial reporting for firms with lower short- 
term debt compared to the firms with higher level of short-term debt.

Lara et al. (2016) examined the impact of conservatism on investment efficiency by using the data of non-financial companies for a long period from 1990 to 2007. Conservatism is one of the characteristics included in accounting quality, therefore their study is a detailed analysis in the same strand of research. They hypothesized that conservatism helps resolving debt-equity conflicts, enhances access to financing sources and limits underinvestment. The results showed that when the firms are prone to underinvestment, more conservative firms make more investments and raise more debt. However, in case of overinvestment proneness, conservatism decreases investments.

Julio and Yook (2016) investigated the relationship between earnings management and investment efficiency by using a large data set covering 99,528 firm-year observations. They found a concave relationship between earnings management measured as the absolute value of discretionary accruals and the firms' investment sensitivity to investment opportunities. They concluded that this concave relationship implies marginal impact of earnings management on the efficiency of investment decisions decreases with the amount of earnings management.

Linhares et al. (2018) searched for the relationship between earnings management and investment efficiency by using the data of Brazilian companies for the period of 1996 to 2012. They established a benchmark for investment efficiency and evaluated the probability of over and under investments with respect to the benchmark in companies engaged in earnings management. They concluded that a higher level of earnings management is associated with a greater probability of deviating from the benchmark investment level.

Carvalho and Kalatzis (2018) conducted a study examining the relationship between accrual quality, financial constraint and investment decisions by using a sample of 958 non-financial firms from seven Latin American countries for the period of 1992-2009. They categorized the companies as with high- or low-quality earnings and analyzed the determinants of investment for each group. They found that the level of earnings quality affects the determinants of investment and investment-cash flow sensitivity. They also categorized the firms making inefficient investment decisions as overinvesting and underinvesting firms and found that investments of overinvesting group are positively associated with low earnings quality whereas investments of underinvesting group are negatively associated with low earnings quality.

\section{Research Sample and Methodology}

The paper takes companies in GCC countries (Bahrain-BAH, Kuwait-KWT, Oman-OMN, Qatar-QTR, Saudi Arabia-SAU, and United Arab Emirates-UAE) into consideration and we selected listed production companies from these countries. We eliminated the companies lacking data between these periods to keep the data balanced. We also took out some companies with extreme values. The sample consists of 184 companies and its time dimension is between 2009 and 2015. The distribution of companies among countries are; 7 companies from Bahrain, 46 companies from Kuwait, 41 companies from Oman, 12 companies from Qatar, 56 companies from Saudi Arabia, and 22 companies from United Arab Emirates. Data is collected from Thomson Reuters Eikon financial database.

We constructed two groups of models on the study, the first group includes model 1 , which is for estimating discretionary accruals of companies, and the second group includes models 2 to 7 , which are on the relationship between earnings management and investment decisions.

Accruals are considered as the key element in earnings management studies because it is assumed that earnings management can be practised by manipulating accruals. Accruals provide many options to the management to manipulate earnings than the cash earnings do. In the estimation of earnings management, we used the model developed by Kothari et al. (2005) to calculate discretionary accruals. The difference of their model than the preceding ones is that they add ROA variable to control for companies' performances. Otherwise some companies may be perceived as they are manipulating earnings. Additionally, we added control variables to the model to eliminate country differences. Instead of using ordinary dummy variables, we added two macro-economic indicators for each country 
and year. This would help us to control country specific effects as well as macroeconomic impacts during time. We calculated total accruals (ACCR) as the difference between Income before Extraordinary Items and Operating Cash Flows, this method is called cash flow approach. Jones (1991) has calculated total accruals using balance sheet approach; however, Hribar and Collins (2002) noted that cash flow approach provides results that are more precise. It also is easy to compute and it needs less variables than balance sheet approach. The mechanics of discretionary accruals can be formulated as:

\section{1. $\quad$ DIF $=$ Total Accruals - Estimated Accruals}

We find total accruals by subtracting Operating Cash Flows from Income Before Extraordinary Items. Then we find estimated accruals (ACCR) from equation 2 which is presented below. The difference between these two accruals show as the magnitude of earnings management for each company, the higher the (DIF) variable, more likely a firm is engaged in manipulating earnings. To estimate normal accruals, we constructed following model:

2. $\frac{A C C R_{i, t}}{T A_{i, t-1}}=\beta_{0}+\beta_{1} \frac{1}{T A_{i, t-1}}+\beta_{2} \frac{(\Delta R e v-\Delta R e c)_{i, t}}{T A_{i, t-1}}+\beta_{3} \frac{P P E_{i, t}}{T A_{i, t-1}}+\beta_{4} R O A_{i, t}+\varepsilon_{i, t}$

$\boldsymbol{A C C R}_{i, t} \quad$ : Total Accruals divided to lagged total assets for firm $i$ in year $t$,

$\mathbf{I} / \boldsymbol{T A}_{i, t} \quad: \mathbf{1}$ divided to lagged total assets for firm $i$ in year $t$,

$(\Delta \operatorname{Rev}-\Delta \operatorname{Rec})_{i, t}:$ Change in revenues minus change in receivables divided to lagged total assets for firm $i$ in year $t$,

$\boldsymbol{P P E}_{i, t} \quad$ : Property, Plant and Equipment divided to lagged total assets for firm $i$ in year $t$,

$\boldsymbol{R O A}_{i, t} \quad$ : Return on Assets for firm $i$ in year $t$,

$\boldsymbol{\varepsilon}_{i, t} \quad$ : Disturbance term for firm $i$ in year $t$.

The sample consists of 184 cross section units (firms) and 7 time units (years). We applied panel data methods and depending on the Hausman Test, we applied random effects model to estimate discretionary accruals. We generated regression results with robust standard errors to eliminate heteroskedasticity and as our time dimension is not long, we did not check for serial or autocorrelation.

Once we gathered the regression results of equation 2, we computed estimated accruals using the coefficients generated in regression model, and we took the difference between estimated accruals and total accruals.

We constructed models including difference between estimated and total (reported) accruals (DIF), debt ratio (DR), Tobin's Q (TOBIN), sales growth (SG), asset size (LNTA) and country specific macroeconomic indicators (GDPBAH, GDPKWT, GDPOMN, GDPQTR, GDPSAU, GDPUAE) as independent variables, and capital expenditures divided to lagged total assets (IRTA), and capital expenditures divided to lagged property plant and equipment (IRPPE) as dependent variables. We computed debt ratio as liabilities divided to total assets and Tobin's Q is calculated as market capitalisation divided to total common equity. Additionally, we took natural logarithm of assets to reduce variance in our model. We constructed regression models for both dependent variables separately.

Companies take investment decisions after a thorough decision process in time. After a decision of capital investment, companies those have the intention of manipulating earnings, may start this manipulation in the years prior to capital expenditure. Hence, we constructed models regarding time differences between potential earnings management practices and investments, consecutively investment and manipulation in the same year, investment follows manipulation after one year and investment following manipulation after two years.

To analyse the effects of discretionary accruals on investment decisions, we constructed following models:

3. IRPPE $E_{i, t}=\beta_{0}+\beta_{1} D I F_{i, t}+\beta_{2} D R_{i, t}+\beta_{3}$ Tobin $_{i, t}+\beta_{4}$ lnta $_{i, t}+\beta_{5} s g_{i, t}+\alpha G D P D u m_{j, t}+\varepsilon_{i, t}$

4. IRTA $A_{i, t}=\beta_{0}+\beta_{1} D_{I F} F_{i, t}+\beta_{2} D R_{i, t}+\beta_{3}$ Tobin $_{i, t}+\beta_{4} \operatorname{lnta}_{i, t}+\beta_{5} s g_{i, t}+\alpha G D P D u m_{j, t}+\varepsilon_{i, t}$

5. IRPPE $E_{i, t}=\beta_{0}+\beta_{1} D I F_{i, t-1}+\beta_{2} D R_{i, t}+\beta_{3}$ Tobin $_{i, t}+\beta_{4}$ lnta $_{i, t}+\beta_{5} s g_{i, t}+\alpha G D P D u m_{j, t}+\varepsilon_{i, t}$

6. IRTA $A_{i, t}=\beta_{0}+\beta_{1} D_{I} F_{i, t-1}+\beta_{2} D R_{i, t}+\beta_{3}$ Tobin $_{i, t}+\beta_{4}$ lnta $_{i, t}+\beta_{5} \operatorname{sg}_{i, t}+\alpha G D P D u m_{j, t}+\varepsilon_{i, t}$

7. IRPPE $E_{i, t}=\beta_{0}+\beta_{1} D I F_{i, t-2}+\beta_{2} D R_{i, t}+\beta_{3}$ Tobin $_{i, t}+\beta_{4} \operatorname{lnta}_{i, t}+\beta_{5} s g_{i, t}+\alpha G D P D u m_{j, t}+\varepsilon_{i, t}$

8. IRTA $A_{i, t}=\beta_{0}+\beta_{1} D_{I} F_{i, t-2}+\beta_{2} D R_{i, t}+\beta_{3}$ Tobin $_{i, t}+\beta_{4}$ lnta $_{i, t}+\beta_{5}$ sg $_{i, t}+\alpha G D P D u m_{j, t}+\varepsilon_{i, t}$

IRTA : Capital Expenditures divided to Total Assets for firm $i$ in year $t$, 


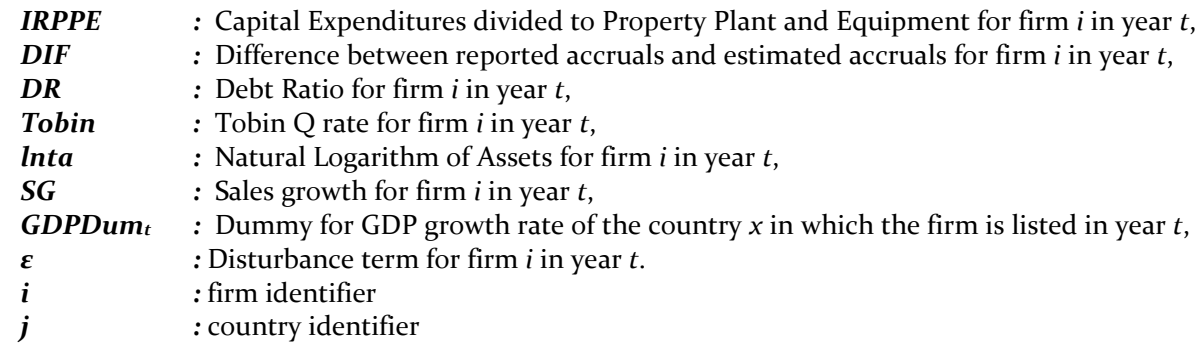

\section{The Results of Analyses and Findings}

This section includes two parts. Firstly, the results and analyses of discretionary accruals are delivered. The second part of this section comprises of the analysis focusing on the relationship between investment and discretionary accruals.

\subsection{Results and Analyses of Discretionary Accruals (Equation 1)}

We used performance adjusted model by Kothari, et al. (2005) to estimate discretionary accruals. In Table 1, the descriptive statistics of variables for estimating discretionary accruals are provided.

Table 1: Descriptive statistics of independent variables of eq.1

\begin{tabular}{|l|c|c|c|c|c|}
\hline Variable & Observation & Mean & Std. Dev. & Min & Max \\
\hline ACCR & 1,288 & -0.0259 & 0.0768 & -0.5783 & 0.4414 \\
\hline 1/TA & 1,288 & $1.33 \mathrm{E}-08$ & $2.36 \mathrm{E}-08$ & $1.10 \mathrm{E}-11$ & $1.70 \mathrm{E}-\mathrm{o} 7$ \\
\hline$\Delta$ REV- $\triangle$ REC & 1,288 & 0.0201 & 0.1442 & -0.8243 & 0.9034 \\
\hline PPE & 1,288 & 0.3968 & 0.2522 & 0.0000 & 1.6368 \\
\hline ROA & 1,288 & 0.0600 & 0.0823 & -0.5815 & 0.4398 \\
\hline
\end{tabular}

The variable "Accruals - (ACCR)" has a negative mean, around $2.6 \%$ of lagged total assets. In this model, we formulated accruals as operating profit minus operating cash flows. Hence, we can state that, firms report more operating cash flows than their operating income. PPE is around $40 \%$ of lagged total assets whereas ROA is around 6\%.

Table 2: Pairwise correlations of variables of eq.1

\begin{tabular}{|l|c|c|c|c|c|}
\hline & ACCR & 1/TA & $\Delta$ REV- $\mathbf{R E C}$ & PPE & ROA \\
\hline ACCR & 1 & & & & \\
\hline 1/TA & -0.013 & 1 & & & \\
\hline$\Delta$ REV-DREC & ${ }^{* *} 0.1011$ & -0.0004 & 1 & & 1 \\
\hline PPE & ${ }^{* *}-0.0833$ & 0.0284 & 0.0386 & ${ }^{* *} 0.0584$ & 1 \\
\hline ROA & ${ }^{* *} 0.2790$ & 0.0399 & ${ }^{* *} 0.1554$ & & \\
\hline
\end{tabular}

** Significant at $5 \%$

Correlation matrix (Table 2) shows a significant correlation between the dependent variable (ACCR) and three independent variables: $\triangle$ REV- $\triangle$ REC, PPE and ROA. Secondly, there is not a significant evidence for multicollinearity as the absolute value of correlations among independent variables do not exceed o.8. 
Table 3: Regression results of eq.1

\begin{tabular}{l|ccc} 
& Coefficients & Std. Err. & t \\
\hline Constant $\left(\boldsymbol{\beta}_{\mathbf{o}}\right)$ & -0.0327 & 0.008 & $* * * 3.90$ \\
1/TA & -151442.4 & 128757.6 & 1.18 \\
$\Delta$ REV-DREC & 0.0293 & 0.025 & 1.18 \\
PPE & -0.0298 & 0.011 & $* * * 2.83$ \\
ROA & 0.3065 & 0.065 & $* * * 4.74$ \\
BAH & 0.0098 & 0.011 & 0.89 \\
KWT & -0.0147 & 0.008 & $* 1.73$ \\
OMN & 0.0132 & 0.009 & 1.50 \\
QTR & 0.0137 & 0.013 & 1.09 \\
UAE & 0.0101 & 0.008 & 1.31 \\
\hline
\end{tabular}

* Significant at $10 \%,{ }^{* *}$ significant at $5 \%,{ }^{* * *}$ significant at $1 \%$

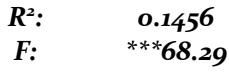

The results shown in Table 3 suggest a strong significant effect of PPE and ROA variables on accruals. However, 1 /TA and $\triangle$ REV- $\triangle$ REC variables do not have a significant effect on accruals. $1 /$ TA is computed as 1 divided to lagged total assets. As assets increase, we expect accruals will increase because increase in assets may inflate revenue and expense accruals. PPE is also inversely related with accruals because of depreciation expenses. An increase in depreciation expenses results in less operating income and less accruals. ROA, on the other side, is positively related to accruals because an increase in net income stems from increase in operating income which would inflate accruals evidently. Though, $\mathrm{R}^{2}$ is low with $14.6 \%$, the model holds overall significance at $1 \%$.

\subsection{Results and Analyses of Investment Decisions (Equations 2 to 7)}

In this part of study, we analysed the relation of investment behaviour of companies and their tendency to manipulate earnings. To see potential effect of earnings management on investments, we took two dependent variables and three time dimensions and constructed six models. Our models consist of two investment rates as dependent variables, namely IRTA and IRPPE. We constructed models to see the effect of discretionary accruals in three different periods. First time dimension includes the investment rates and discretionary accruals (DIF) for same year, second time dimension includes investment rates with one year lagged DIF, and third time dimension includes investment rates with two year lagged DIF. DIF is calculated as the difference between reported accruals and estimated accruals. Reported accruals are found by taking difference between operating profits and operating cash flows, whereas estimated accruals are gathered as using coefficients in earning estimation of accruals (in equation 1).

Table 4: Descriptive statistics of eq.2 and 3

\begin{tabular}{|l|c|c|c|c|c|}
\hline Variables & Observation & Mean & Std. Dev. & Min & Max \\
\hline IRPPE & 1,288 & 0.2109 & 0.4575 & 0.0000 & 12.7923 \\
\hline IRTA & 1,288 & 0.0556 & 0.0699 & 0.0000 & 0.7073 \\
\hline DIF & 1,288 & 0.0000 & 0.0725 & -0.3458 & 0.4657 \\
\hline DR & 1,288 & 0.3333 & 0.2048 & 0.0000 & 0.9454 \\
\hline TOBIN & 1,288 & 4.0858 & 3.9340 & 0.1820 & 26.0014 \\
\hline LNTA & 1,288 & 19.3063 & 1.6332 & 15.5500 & 25.2300 \\
\hline SG & 1,288 & 0.1209 & 1.1069 & -0.9182 & 30.7577 \\
\hline
\end{tabular}

Table 4 presents descriptive statistics of variables for equations 2 and 3 . We had 1288 observations with 184 firms and 7 years. Here, mean DIF is slightly higher than o. This figure suggests that reported accruals are marginally higher than estimated accruals. IRPPE is $21 \%$ and IRTA is almost $5.6 \%$. Investment rate is round $20 \%$ of present PPE and only $5.6 \%$ of total assets. 
Table 5: Pairwise correlations of variables of eq.2 and 3

\begin{tabular}{|l|c|c|c|c|c|c|c|}
\hline & IRPPE & IRTA & DIF & DR & TOBIN & LNTA & SG \\
\hline IRPPE & 1 & & & & & & \\
\hline IRTA & ${ }^{* *} 0.3262$ & 1 & & & & & \\
\hline DIF & 0.0238 & -0.038 & 1 & & & & \\
\hline DR & -0.0184 & ${ }^{* *} 0.0652$ & ${ }^{* *} 0.1714$ & 1 & & & \\
\hline TOBIN & 0.0536 & ${ }^{* *} 0.1029$ & ${ }^{* *}-0.1187$ & -0.0091 & 1 & & \\
\hline LNTA & -0.0125 & -0.0363 & ${ }^{* *} 0.057$ & ${ }^{* *} 0.3099$ & ${ }^{* *} 0.1428$ & 1 & \\
\hline SG & ${ }^{* *} 0.5933$ & -0.0128 & ${ }^{* *} 0.094$ & 0.0347 & -0.0318 & ${ }^{* *} 0.0681$ & 1 \\
\hline
\end{tabular}

** Significant at $5 \%$

Correlation matrix exhibits that discretionary accruals (DIF) show a positive weak correlation with IRPPE and it is negatively correlated with IRTA. IRPPE is also correlated with sales growth (SG). IRTA is correlated with debt ratio ("DR"), Tobin's Q rate (TOBIN). Another fact to consider in this table is, we do not observe any evidence for multicollinearity as the correlation coefficients among independent variables (DIF, DR, TOBIN, LNTA, SG) are less than o.8o.

Table 6: Regression results of eq.2 (IRPPE as dependent variable - DIF; same year with IRPPE)

\begin{tabular}{l|ccc|cr} 
& Coefficients & Std. Err. & $\mathbf{t}$ & & \\
\hline Constant $\left(\boldsymbol{\beta}_{\mathbf{0}}\right)$ & -1.212 & 1.456 & -0.83 & & \\
DIF & -0.387 & 0.207 & $*-1.87$ & $\boldsymbol{R}^{2}:$ & $\mathbf{0 . 3 9 2}$ \\
DR & 0.003 & 0.118 & 0.03 & $\boldsymbol{F}:$ & ${ }^{*} \mathbf{1 . 8 6}$ \\
TOBIN & 0.009 & 0.008 & 1.14 & & \\
LNTA & 0.070 & 0.077 & 0.91 & & \\
SG & 0.246 & 0.121 & $* 2.03$ & & \\
GDPBAH & 1.385 & 2.968 & 0.47 & \\
GDPKWT & -0.466 & 0.221 & $* *-2.11$ & \\
GDPOMN & 0.551 & 0.557 & 0.99 & \\
GDPQTR & 0.953 & 1.773 & 0.54 & & \\
GDPUAE & -1.889 & 1.004 & $*-1.88$ &
\end{tabular}

Table 6 shows the regression results of the second equation, which takes IRPPE as dependent variable. Results show overall significance slightly lower than 5\% (0.054) and 0.392 of $^{2}$. Among the partial coefficients, P-value of DIF (o.051) falls in 10\% significance level and SG (0.044) is significant at $5 \%$. The sign of DIF is negative, telling that a downward or negative increase in DIF is significantly leading to a positive increase in IRPPE. Among control variables, GDPUAE and GDPKWT show a dispersing significant pattern. It shows an inverse pattern with the GDP of other countries.

Table 7: Regression results of eq.3 (IRTA as dependent variable - DIF; same year with IRTA)

\begin{tabular}{l|ccc} 
& Coefficients & Std. Err. & t \\
\hline Constant $\left(\beta_{\mathrm{o}}\right)$ & -0.026 & 0.302 & -0.09 \\
DIF & 0.000 & 0.019 & -0.02 \\
DR & 0.015 & 0.031 & 0.48 \\
TOBIN & 0.003 & 0.001 & $* * 2.11$ \\
LNTA & 0.003 & 0.016 & 0.21 \\
SG & 0.000 & 0.001 & 0.69 \\
GDPBAH & 0.342 & 0.182 & $* 1.88$ \\
GDPKWT & -0.051 & 0.067 & -0.75 \\
GDPOMN & -0.007 & 0.133 & -0.06 \\
GDPQTR & 0.076 & 0.085 & 0.9 \\
GDPUAE & -0.235 & 0.129 & $*-1.82$ \\
\hline
\end{tabular}

* Significant at $10 \%,{ }^{* *}$ significant at $5 \%,{ }^{* * *}$ significant at $1 \%$ 
In the third equation, we took IRTA as dependent variable. The results are presented in table 7. Overall significance is held at $10 \%$. The model, however, has a lower $\mathrm{R}^{2}$ (o.013). This model provides a lower significance level compared to model 2, it suggests an insignificant effect of DIF. Opposite of previous model, despite its lack of significance, DIF and IRTA have positive signs and an upward change in DIF will increase IRTA.

In this part of analysis, we checked for the potential effect of discretionary accruals for the following year's investments. We regressed investment rates using same independent variables in previous models (models 2 and 3 ) with a difference that we took previous year's discretionary accruals. The motive behind this change results from the idea that, companies which have a tendency to manipulate earnings may take this action prior to the investment years. The period covers 6 years, from 2010 to 2015 in all variables except DIF which is composed of the observations from 2009 to 2014.

Table 8: Descriptive statistics of eq.4 and 5

\begin{tabular}{|l|c|c|c|c|c|}
\hline Variables & Observation & Mean & Std. Dev. & Min & Max \\
\hline IRPPE & 1,104 & 0.2053 & 0.4738 & 0.0000 & 12.7923 \\
\hline IRTA & 1,104 & 0.0540 & 0.0677 & 0.0000 & 0.7073 \\
\hline DIF & 1,104 & 0.0001 & 0.0709 & -0.3458 & 0.4657 \\
\hline DR & 1,104 & 0.3331 & 0.2048 & 0.0000 & 0.9454 \\
\hline TOBIN & 1,104 & 4.1713 & 4.0473 & 0.2435 & 26.0014 \\
\hline LNTA & 1,104 & 19.3318 & 1.6332 & 15.5500 & 25.2300 \\
\hline SG & 1,104 & 0.1174 & 0.9978 & -0.9182 & 30.7577 \\
\hline
\end{tabular}

The descriptive statistics (Table 8) present similar statistics with previous models. DIF is close to o and it has a positive sign. Additionally, IRPPE and IRTA means are close to the values portrayed in Table 4 . Other variables also follow similar patterns with those included in data used in equations 2 and 3 (see table 4).

Table 9: Pairwise correlations of variables of eq.4 and 5

\begin{tabular}{|l|c|c|c|c|c|c|c|}
\hline & IRPPE & IRTA & DIF & DR & TOBIN & LNTA & SG \\
\hline IRPPE & 1 & & & & & & \\
\hline IRTA & ${ }^{* *} 0.305$ & 1 & & & & & \\
\hline DIF & 0.0394 & -0.0472 & 1 & & & & \\
\hline DR & -0.0315 & 0.0405 & ${ }^{* *} 0.1971$ & 1 & & & \\
\hline TOBIN & ${ }^{* *} 0.0643$ & ${ }^{* *} 0.1138$ & ${ }^{* *}-0.1525$ & -0.0101 & 1 & & \\
\hline LNTA & -0.017 & -0.0542 & ${ }^{* *} 0.072$ & ${ }^{* *} 0.3166$ & ${ }^{* *} 0.1442$ & 1 & \\
\hline SG & ${ }^{* *} 0.7485$ & -0.0039 & 0.0439 & -0.0078 & -0.0269 & 0.0387 & 1 \\
\hline
\end{tabular}

** Significant at $5 \%$

Pairwise correlations exhibit attracting results in Table 9. IRPPE has a significant correlation only with sales growth among independent variables whereas IRTA is correlated with Debt ratio and Tobin. Yet, there is not any significant correlation between DIF and dependent variables (IRPPE and IRTA). Another point to consider in correlation table is, we observe no evidence for multicollinearity among independent variables. 
Table 10: Regression results of eq.4 (IRPPE as dependent variable - DIF; 1-year difference with IRPPE)

\begin{tabular}{|c|c|c|c|c|c|}
\hline & Coefficients & Std. Err. & t & & \\
\hline Constant $\left(\beta_{0}\right)$ & -0.798 & 1.331 & -0.6 & & \\
\hline DIF & 0.038 & 0.115 & 0.33 & $R^{2}:$ & 0.604 \\
\hline DR & -0.163 & 0.114 & -1.43 & $F:$ & $* * * * 5.63$ \\
\hline TOBIN & 0.009 & 0.008 & 1.2 & & \\
\hline LNTA & 0.051 & 0.069 & 0.73 & & \\
\hline SG & 0.352 & 0.052 & $* * * 6.83$ & & \\
\hline GDPBAH & 0.165 & 3.967 & 0.04 & & \\
\hline GDPKWT & -0.473 & 0.235 & $* *-2.01$ & & \\
\hline GDPOMN & 0.344 & 0.633 & 0.54 & & \\
\hline GDPQTR & 1.286 & 1.867 & 0.69 & & \\
\hline GDPUAE & -2.087 & 1.185 & ${ }^{*}-1.76$ & & \\
\hline
\end{tabular}

Table 10 shows the $4^{\text {th }}$ equation in which IRPPE is dependent variable and lagged DIF, DR, TOBIN, LNTA, SG and country control variables as independent variables. The coefficients of variables cannot hold partial significance except SG, GDPKWT and GDPUAE. However, the model has overall significance at $1 \%$ and $\mathrm{R}^{2}$ is 0.60 . As a result, it can be suggested that IRPPE are not depending on lagged discretionary accruals and other variables. Among the control variables, we observe a negative dispersion of UAE and Kuwait from other counterparts.

Table 11: Regression results of eq.5 (IRTA as dependent variable - DIF; 1-year difference with IRTA)

\begin{tabular}{|c|c|c|c|c|c|}
\hline & Coefficients & Std. Err. & $\mathbf{t}$ & & \\
\hline Constant $\left(\beta_{o}\right)$ & -0.244 & 0.335 & -0.73 & & \\
\hline DIF & 0.005 & 0.030 & 0.18 & $R^{2}$ : & 0.011 \\
\hline DR & 0.002 & 0.038 & 0.05 & $F:$ & $* *_{2.00}$ \\
\hline TOBIN & 0.002 & 0.002 & 1.6 & & \\
\hline LNTA & 0.015 & 0.018 & 0.85 & & \\
\hline SG & 0.001 & 0.001 & 1.07 & & \\
\hline GDPBAH & 0.371 & 0.189 & ${ }^{*} 1.96$ & & \\
\hline GDPKWT & -0.032 & 0.061 & -0.53 & & \\
\hline GDPOMN & -0.059 & 0.133 & -0.44 & & \\
\hline GDPQTR & 0.029 & 0.077 & 0.37 & & \\
\hline GDPUAE & -0.236 & 0.183 & -1.29 & & \\
\hline
\end{tabular}

* Significant at $10 \%,{ }^{* *}$ significant at $5 \%,{ }^{* * *}$ significant at $1 \%$

In table 11, regression results for equation 5 in which IRTA and its regressors occur are reported. DIF is lagged by one year. The results reveal all variables except GDPBAH are insignificant in the model. As a result, lagged accruals do not have any influence on IRTA. As we check for control variables, only GDPBAH is significantly and positively correlated with our benchmark variable which is GDP of Saudi Arabia (GDPSAU). The model has overall significance at $5 \%$ however the $\mathrm{R}^{2}$ (o.oul) is extremely low which is similar to $\mathrm{R}^{2}$ of equation 3 (see table 7 .)

In the last part of analysis, we tested the possible effects of manipulated earnings to investment decisions on the second consecutive year and constructed equations 6 and 7. The data has 920 observations comprised of 184 companies and 5 years, from 2011 to 2015 . The following tables (table 12 and table 13) provides descriptive statistics and correlation tables of the corresponding equations. 
Table 12: Descriptive Statistics of variables of eq. 6 and 7

\begin{tabular}{|l|c|c|c|c|c|}
\hline Variables & Observation & Mean & Std. Dev. & Min & Max \\
\hline IRPPE & 920 & 0.2028 & 0.4886 & 0.0000 & 12.7923 \\
\hline IRTA & 920 & 0.0530 & 0.0635 & 0.0000 & 0.4993 \\
\hline DIF & 920 & 0.0005 & 0.0722 & -0.3393 & 0.4657 \\
\hline DR & 920 & 0.3349 & 0.2052 & 0.0000 & 0.9454 \\
\hline TOBIN & 920 & 4.2403 & 4.2083 & 0.2435 & 26.0014 \\
\hline LNTA & 920 & 19.3567 & 1.6322 & 15.5500 & 25.2300 \\
\hline SG & 920 & 0.1148 & 1.0537 & -0.9182 & 30.7577 \\
\hline
\end{tabular}

Descriptive statistics (Table 12) reveal similar figures with preceding numbers. Correlations among variables reveal IRPPE is correlated with TOBIN and SG among independent variables and IRTA has a significant correlation with DIF, TOBIN and LNTA. Correlation coefficients among independent variables (Table 13) do not exhibit any evidence for multicollinearity.

Table 13: Pairwise correlations of variables of eq. 6 and 7

\begin{tabular}{|l|c|c|c|c|c|c|c|}
\hline & IRPPE & IRTA & DIF & DR & TOBIN & LNTA & SG \\
\hline IRPPE & 1 & & & & & & \\
\hline IRTA & ${ }^{* *} 0.2791$ & 1 & & & & & \\
\hline DIF & 0.0153 & ${ }^{* *}-0.0906$ & 1 & & & & \\
\hline DR & -0.0203 & 0.0408 & ${ }^{* *} 0.1968$ & 1 & & & \\
\hline TOBIN & ${ }^{* *} 0.0744$ & ${ }^{* *} 0.1272$ & ${ }^{* *}-0.1591$ & -0.0153 & 1 & & \\
\hline LNTA & -0.0071 & ${ }^{* *}-0.0681$ & ${ }^{* *} 0.0783$ & ${ }^{* *} 0.3238$ & ${ }^{* *} 0.1396$ & 1 & \\
\hline SG & ${ }^{* *} 0.8293$ & -0.0053 & 0.0135 & -0.0118 & -0.0228 & 0.0427 & 1 \\
\hline
\end{tabular}

** Significant at 5\%

Table 14 shows regression results of model 6 which considers the effects on 2-year lagged discretionary accruals on IRPPE. Results show no significant relationship between discretionary accruals and IRPPE. IRPPE is significantly related to sales growth (SG) positively. We also observed a higher GDP of UAE positively differentiates from benchmark country (Saudi Arabia) whereas Kuwait has a significant lower GDP growth compared to Saudi Arabia, other countries do not have a significant dispersion. Though partial significances of variables are not caught, the model has a relatively high goodness of fit with $73 \%$ and overall significance at $1 \%$.

Table 14: Regression results of eq.6 (IRPPE as dependent variable - DIF; 2-year difference with IRPPE)

\begin{tabular}{|c|c|c|c|c|c|}
\hline & Coefficients & Std. Err. & $\mathbf{t}$ & & \\
\hline Constant $\left(\beta_{o}\right)$ & -2.306 & 1.549 & -1.49 & & \\
\hline DIF & 0.086 & 0.173 & 0.5 & $R^{2}$ : & 0.7316 \\
\hline DR & -0.156 & 0.125 & -1.25 & $F:$ & $* * * 19.82$ \\
\hline TOBIN & 0.004 & 0.009 & 0.48 & & \\
\hline LNTA & 0.128 & 0.081 & 1.58 & & \\
\hline SG & 0.375 & 0.028 & $* * * 13.26$ & & \\
\hline GDPBAH & 0.923 & 3.462 & 0.27 & & \\
\hline GDPKWT & -0.613 & 0.326 & ${ }^{*}-1.88$ & & \\
\hline GDPOMN & 0.251 & 0.668 & 0.38 & & \\
\hline GDPQTR & -0.406 & 0.291 & -1.4 & & \\
\hline GDPUAE & 2.708 & 1.382 & * 1.96 & & \\
\hline
\end{tabular}

${ }^{*}$ Significant at $10 \%,{ }^{* *}$ significant at $5 \%,{ }^{* * *}$ significant at $1 \%$

The last model (eq.7) takes IRTA as dependent variable and 2-year lagged DIF and other variables as 
independent variables. The results of this model are presented in table 15 . We observed a significant effect of total assets (LNTA), constant term, GDPBAH and GDPUAE. However, there is no significant relation between discretionary accruals (DIF) and IRTA. The model has a poor $\mathrm{R}^{2}(0.022)$ despite $1 \%$ overall significance.

Table 15: Regression results of eq.7 (IRTA as dependent variable - DIF; 2-year difference with IRTA)

\begin{tabular}{|c|c|c|c|c|c|}
\hline & Coefficients & Std. Err. & $\mathbf{t}$ & & \\
\hline Constant $\left(\beta_{o}\right)$ & -0.781 & 0.430 & ${ }^{*}-1.82$ & & \\
\hline DIF & -0.032 & 0.041 & -0.79 & $R^{2}$ : & 0.022 \\
\hline DR & 0.003 & 0.040 & 0.07 & $F:$ & $* * * 3.27$ \\
\hline TOBIN & 0.001 & 0.002 & 0.89 & & \\
\hline LNTA & 0.043 & 0.022 & * 1.89 & & \\
\hline SG & 0.000 & 0.001 & 0.32 & & \\
\hline GDPBAH & 0.411 & 0.181 & $* * 2.27$ & & \\
\hline GDPKWT & -0.001 & 0.069 & -0.01 & & \\
\hline GDPOMN & -0.088 & 0.142 & -0.62 & & \\
\hline GDPQTR & 0.049 & 0.119 & 0.41 & & \\
\hline GDPUAE & 0.833 & 0.394 & ${ }^{* *} 2.11$ & & \\
\hline
\end{tabular}

* Significant at $10 \%,{ }^{* *}$ significant at 5\%, ** significant at $1 \%$

\section{Conclusion}

In this study, we examined the relationship between discretionary accruals and corporate investment decisions. We firstly estimated discretionary accruals scores of firms using performance adjusted model of Kothari et al. (2005). Our regression results in estimating accruals have satisfactory partial and overall significances. When we analyse the means of variables, we noticed that the mean reported accruals were negative. This fact may result from either prudent accounting policies or tendency of companies to report less earnings in order to avoid taxation. Companies may want to decrease their earnings and getting a tax advantage prior to or during capital expenditures since they would have a burden of cash outflows during the acquisition and setups of tangibles.

In the second part of analysis we tested the relationship between investment decisions of companies with discretionary accruals (DIF). We selected two dependent variables named as IRTA, and IRPPE, then tested their dependency to DIF in same year, one year before, and two years before along with other variables. We constructed 6 models in total.

As we take a look to models including IRPPE as dependent variable, which is derived as the division of PPE to lagged total assets, only DIF in the same year have a significant effect on IRPPE, whereas previous one and two years' DIF do not have any significant effect.

IRTA results have similarities with the patterns to IRPPE. In the models those took IRTA as dependent variable, all DIF variables for different time dimensions fail to have significant effect on the dependent variables. Furthermore, IRTA and DIF relationship has lower significance compared to IRPPE and DIF.

The timing differences among models reveal that the explanatory powers and overall significances of models increase as the dataset has shorter periods. In 7-year period, $\mathrm{R}^{2}$ and overall significances are not remarkably high compared to 6-year and 5-year models. Additionally, we observed that using PPE as an indicator of investment decisions of companies provide more precise results than those using IRTA. The reason may be since PPE is more sensitive to investment decisions however, total assets have many other accounts which are not affected from investment decisions.

To sum up, despite some weak evidence, we can hardly state that we observed companies are engaged in accrual manipulations to provide an advantage for their investment decisions. 


\section{References}

Biddle, G.C., Hilary, G.(2006).Accounting quality and firm-level capital investment. Accounting Review 81 (5), 963982.

Biddle, G.C., Hilary,G., and Verdi,R.S.(2009).How does financial reporting quality relate to investment efficiency?.Journal of Accounting and Economics 48, 112-131

Carvalho,F.L . and Kalatzis,A.E.G. (2018).Earnings quality, investment decisions, and financial constraint.Review of Business Management, v.20 n.4, pp.573-598,

Ching-Hai Jiang Hsiang-Lan Chen Yen-Sheng Huang.(2006).Capital expenditures and corporate Earnings.Managerial Finance, Vol. 32 Issue 11 pp. $853-861$

Cohen,D.A., Dey,A., and Lys, T.Z. (2008). Real and Accrual-Based Earnings Management in the Pre- and PostSarbanes-Oxley Periods. The Accounting Review, 83, no.3, pp.757-787

DeAngelo, L.E.(1986). Accounting Numbers as Market Valuation Substitutes: A Study of Management Buyouts of Public Stockholders. The Accounting Review 61, no. 3, pp.400-420.

Dechow, P.M., Sloan,R.G and Sweeney,A.P. (1995).Detecting Earnings Management. The Accounting Review 2o, no. 2, pp.193-225.

Gomariz, F. C., and Ballesta, J. P. S. (2014).Financial reporting quality, debt maturity and investment efficiency. Journal of Banking \& Finance, 40, 494-506.

Healy, P.M. (1985).The Effect of Bonus Schemes on Accounting Decisions. Journal of Accounting and Economics 7 , no. 1-3, pp.85-107.

Healy, P.M., and Wahlen, J.M. (1999). A Review of the Earnings Management Literature and Its Implications for Standard Setting. Accounting Horizons 13, no. 4, pp.365-383.

Hribar, P. and Collins, D.W (2002). Errors in Estimating Accruals: Implications for Empirical Research. Journal of Accounting Research 40, no. 1, pp.105-134.

Jones, JJ. (1991). Earnings Management During Import Relief Investigations. Journal of Accounting Research 29, no. 2, pp. 193-228.

Julio, Brandon, and Youngsuk Yook (2016). Earnings Management and Corporate Investment Decisions. Finance and Economics Discussion Series 2016-086. Washington: Board of Governors of the Federal Reserve System

Kapellas K, Siougle G (2017).Financial Reporting Practices and Investment Decisions: A Review of the Literature. Industrial Engineering $\mathcal{E}$ Management 6: 235, doi:10.4172/2169-0316.1000235

Kothari, S.P., Leone, A.J and Wasley, C.E. (2005). Performance Matched Discretionary Accrual Measures. Journal of Accounting E Economics 39, no. 1, pp.163-197.

Lambert, R., C. Leuz, and R. Verrecchia, 2007. Accounting information, disclosure, and the cost of capital. Journal of Accounting Research 45, 385-420.

Lara, J. M. G., Osma, B. G., \& Penalva, F. (2016). Accounting conservatism and firm investment efficiency. Journal of Accounting and Economics, 61(1), 221-238.

Li,F., (2011). Earnings Quality Based on Corporate Investment Decisions. Journal of Accounting Research, Vol. 49, No. 3, pp. $721-752$

Linhares,F.S., Costa,F.M. and Beiruth,A.X., (2018). Earnings management and investment efficiency. Review of Business Management, v.20 n2, pp.295-310

McNichols, M. F., \& Stubben, S. R. (2008). Does earnings management affect firms' investment decisions? The Accounting Review, 83(6), 1571- 1603.

Tang, Vicki Wei and Li, Kevin K., (2008).Earnings Quality and Future Capital Investment: Evidence from Discretionary Accruals. Available at SSRN: https://ssrn.com/abstract=1107492 or http://dx.doi.org/10.2139/ssrn.1107492

Zhang,X.F., (2007). Accruals, Investment, and the Accrual Anomaly. The Accounting Review, Vol. 82, No. 5, pp. 13331363 